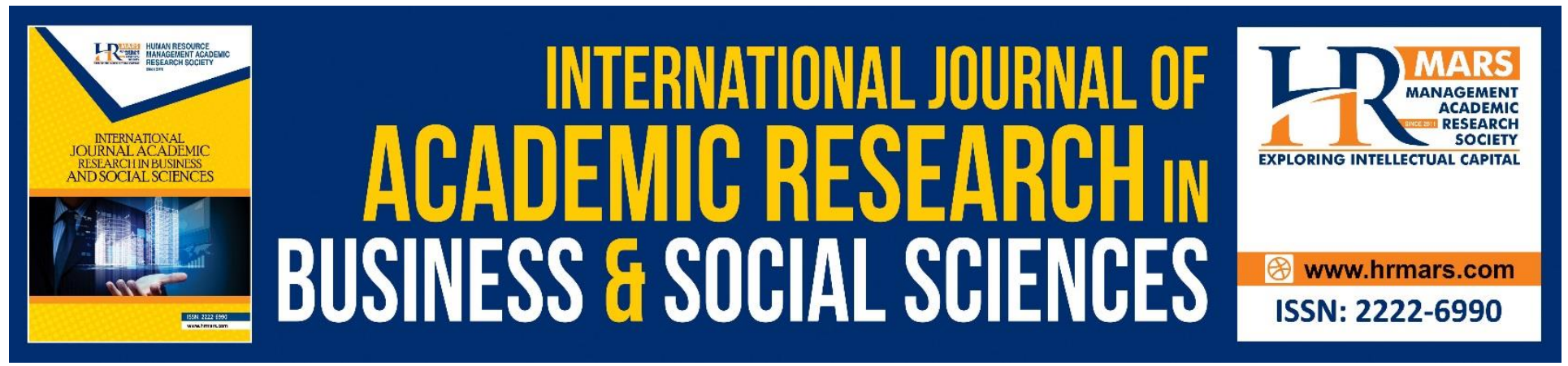

\title{
Unlocking "Black Box": Mediating Role of Knowledge Process Capability on HRM Practices and Innovative Performance
}

Rania Jamal Saleh Altarawneh, Wan Norhayate Wan Daud, Fakhrul Anwar Zainol, Norfadzilah Rashid, Asyraf Afthanorhan

To Link this Article: http://dx.doi.org/10.6007/IJARBSS/v8-i11/5162 DOI: $10.6007 /$ IJARBSS/v8-i11/5162

Received: 02 Nov 2018, Revised: 02 Dec 2018, Accepted: 06 Dec 2018

Published Online: 07 Dec 2018

In-Text Citation: (Altarawneh, Wan Norhayate Wan DaudZainol, Rashid, \& Afthanorhan, 2018)

To Cite this Article: Altarawneh, R. J. S., Wan Norhayate Wan DaudZainol, F. A., Rashid, N., \& Afthanorhan, A. (2018). Unlocking "Black Box": Mediating Role of Knowledge Process Capability on HRM Practices and Innovative Performance. International Journal of Academic Research in Business and Social Sciences, 8(11), 1192-1208.

\section{Copyright: (c) 2018 The Author(s)}

Published by Human Resource Management Academic Research Society (www.hrmars.com)

This article is published under the Creative Commons Attribution (CC BY 4.0) license. Anyone may reproduce, distribute, translate and create derivative works of this article (for both commercial and non-commercial purposes), subject to full attribution to the original publication and authors. The full terms of this license may be seen at: $\underline{\text { http://creativecommons.org/licences/by/4.0/legalcode }}$

Vol. 8, No. 11, 2018, Pg. 1192 - 1208

Full Terms \& Conditions of access and use can be found at http://hrmars.com/index.php/pages/detail/publication-ethics 


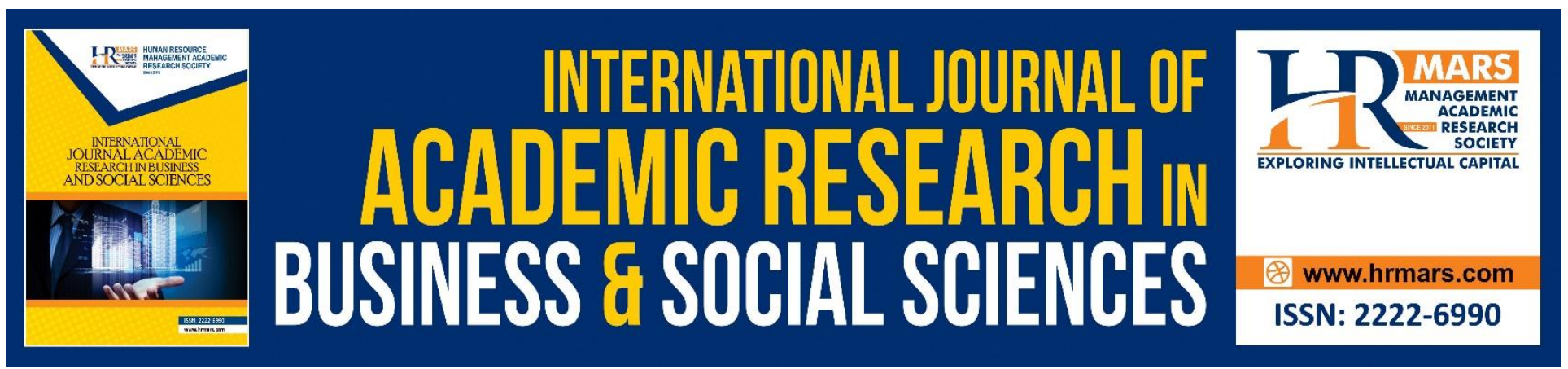

\title{
Unlocking "Black Box": Mediating Role of Knowledge Process Capability on HRM Practices and Innovative Performance
}

\author{
${ }^{1}$ Rania Jamal Saleh Altarawneh, ${ }^{2}$ Wan Norhayate Wan Daud, \\ ${ }^{3}$ Fakhrul Anwar Zainol, ${ }^{4}$ Norfadzilah Rashid, ${ }^{5}$ Asyraf Afthanorhan \\ Faculty of Economics and Management Sciences, Universiti Sultan Zainal Abidin 21300 Kuala Nerus, \\ Terengganu, Malaysia \\ Corresponding Author: wnhayate@unisza.edu.my
}

\begin{abstract}
In this paper, the effect of ; ability-enhancing human resource management practices (staffing, training), motivation-enhancing human resource management practices (compensation, performance appraisal) opportunity to perform-enhancing human resource management practices (involvement, communication), was examined along knowledge process capability (Acquisition process, Conversion process, Application process, Protection process) on innovative performance among Jordanian banks, the construct of innovative performance measured by (Administrative innovation and Technical innovation). The study employed convenience sampling to which 300 questionnaires distributed. This paper contributes of unlocking "black box" problem with mediating role of knowledge process capability as an explanatory factor to understand HRM- innovative performance relationship with the insight of knowledge-based view, ability motivation opportunity (AMO) and resource-based view (RBV) theory. The finding showed a significant impact of (ability, motivation, and opportunity)-enhancing human resource management practices, of knowledge process capability on innovative performance in the Jordanian banks. From the findings, the researcher provided recommendations for the banks regarding strengthening the relationship between their HRM, of knowledge process capability and their performance. The study also offered implications to theory and practice based on the findings.
\end{abstract}

Keywords: HRM Practices, Ability, Motivation, Opportunity Model, Knowledge Process Capability, Innovative Performance.

\section{Introduction}

The banking sector is one of the most critical sectors of the economy of Jordan, contributing to around $11.6 \%$ of Gross Domestic Product (GDP) at constant prices in 2014. The sector has been 
growing in recent years and this growth is reflected by the remarkable rise in the total assets of licensed banks which more than trebled in size from JOD 14.15 billion in assets back in 2000 to JOD 60.5 billion at the end of growth rate of 2013 reflecting 328\% meaning that banks' total assets more than tripled during this period. This growth attributed to the somewhat conservative banking policies adopted by banks in Jordan that enabled the country to withstand the global financial crisis in 2009. Jordan's banking sector is considered to be well developed by regional standards with some businesses, investment, and retail service offerings. The Jordanian banking sector is cautiously managed and effectively supervised by the Central Bank of Jordan (CBJ).

This approach of banking system management has resulted in a set of good macro-prudential indicators and proven resilient to domestic and external shocks over the last few years, such as the global financial crises in 2009 and the what is referred to as the 'Arab Spring' in some countries of the region, maintaining its expansion and growth during 2013. Jordanian banks are already well on the way to satisfying significant components regarding capital adequacy and liquidity (Central Bank of Jordan, 2015) A report published by Jordanian Central Bank (CBJ) (2015), stated that there are 25 banks with 786 branches across the Kingdom, classified into four categories; national commercial banks (13), national Islamic banks (3), foreign commercial bank (8) and foreign Islamic bank (1).

However, the sector has many human resources gaps due to employee's skills and abilities that can summarize as the lack of specific knowledge, experience, the loss of talent for better-paying competition, lack of Selling skills. That mean lack of ability to present bank products attractively, highlight vital positive features, understand and capture the customer needs quickly, ability to establish credibility, cross-selling, up-selling, follow up, humility ,ability to distinguish prospective customer Presentation - communication skills, self-presentation, understanding of customers' background and exact needs and communication skills (Central Bank of Jordan ,2015)

Due to globalization and dynamics markets, many organizations are actively attempting to make additional value to their consumers and increase the quality of their services (Devie, 2011). The work environment became more complicated in the banking sector, competitive and uncertain after the world economic crises, which force banks to protect their competitive positions by delivering high-quality services focused one consumers' loyalty (Ghoneim\&Eltabie, 2014). Based on human factor influence, plays a central role in determining organizational success and providing premium services, factors affecting employees performance rapidly become active research is within the last decades(Matzler\&Renzl,2007).

In the modern environment without limits, banks services relate to growing needs owing to the global economic shifts the job scope of banking employees also has to be kept at standard with the changes as they have to complete their jobs to meet the needs and demands of customers. Although the banking sectors' contribution to the Jordanian economy is high, several issues still exist among the employees. Bank employees have matters cited throughout banks in the nation via the National Union of Bank Employees (NUBE) as internal solutions to the mentioned issues are still elusive (Alvarez, Garcia \& Gouveia, 2016). 
INTERNATIONAL JOURNAL OF ACADEMIC RESEARCH IN BUSINESS AND SOCIAL SCIENCES Vol. 8, No. 11, Nov, 2018, E-ISSN: 2222-6990 @ 2018 HRMARS

Table 01. [development the numbers of banks and branches in Jordan from 2007 to 2015]

\begin{tabular}{|c|c|c|c|c|c|c|}
\hline \multirow[b]{2}{*}{ year } & \multicolumn{2}{|c|}{ No. National banks } & \multicolumn{2}{|c|}{ No. Foreign banks } & \multirow[b]{2}{*}{ total } & \multirow{2}{*}{$\begin{array}{l}\text { No. } \\
\text { branches }\end{array}$} \\
\hline & $\begin{array}{l}\text { No. } \\
\text { Commercial }\end{array}$ & $\begin{array}{l}\text { No. } \\
\text { Islamic }\end{array}$ & $\begin{array}{l}\text { No. } \\
\text { Commercial }\end{array}$ & $\begin{array}{l}\text { No. } \\
\text { Islamic }\end{array}$ & & \\
\hline 2007 & 13 & 2 & 8 & 0 & 23 & 559 \\
\hline 2008 & 13 & 2 & 8 & 0 & 23 & 593 \\
\hline 2009 & 13 & 2 & 8 & 0 & 23 & 619 \\
\hline 2010 & 13 & 3 & 9 & 0 & 25 & 666 \\
\hline 2011 & 13 & 3 & 9 & 1 & 26 & 702 \\
\hline 2012 & 13 & 3 & 9 & 1 & 26 & 722 \\
\hline 2013 & 13 & 3 & 9 & 1 & 26 & 742 \\
\hline 2014 & 13 & 3 & 8 & 1 & 25 & 770 \\
\hline 2015 & 13 & 3 & 8 & 1 & 25 & 786 \\
\hline
\end{tabular}

Source: CBJ report (2015)

Managing human resources of organizations demands the using of different practices that play a significant role in helping organizations create and sustain the performance they desire (Fong et al., 2011; Ortega-Parra \& Sastre-Castillo, 2013) ) as they influence the attitudes and behaviors of employees (Lew, 2011). Human resources are considered critical factors are contributing to an organization's success (Dominguez, 2011). Strategically handling human resources is required to overcome the different challenges organizations face (Othman, 2009). Therefore, effectively managing these sources is of significance to all firms (Juhdi et al., 2011)Banks as Organizations operate in a climate distinguished by unpredictability, anxiety, and change that produce the features of different trials (Bimpitsos \& Petridou, 2012). Such an environment involves many constituents as increased globalization, accelerated technological transformation, and the growing need for qualified employees and enhanced innovation and performance (Vanhala \& Stavrou, 2013). Then organizations try and utilize the resources to gain a competitive advantage (Savaneviciene \& Stakeviciute, 2011).

Strategic human resource management identifies innovation as a crucial enabler for organizations to increase its work value and maintain a competitive advantage in the increasingly complicated and fast-changing environment (Subramaniam and Youndt, 2005). Montes et al., (2004) asserted that Organizations with transcendent innovativeness would be faster in replying to growing environments and in developing new abilities that allow them to attain better performance.Innovation process leads to relies densely on employees' knowledge, expertise, and involvement as essential inputs in the value creation process .Grant, (1996) and Spender, (1996) on their view; the knowledge-based view represents organizations as depositories of knowledge and competencies. Based on this view, earlier studies verify the knowledge and competencies of human resource as essential assets for organizations because of their characteristics of firm-specific, socially involved, and path-dependent (Collins and Clark, 2003; Wright et al., 2001; Youndt). Human resource practices (HRM practices) are the fundamental means by which organization can lead and form the 
INTERNATIONAL JOURNAL OF ACADEMIC RESEARCH IN BUSINESS AND SOCIAL SCIENCES Vol. 8, No. 11, Nov, 2018, E-ISSN: 2222-6990 @ 2018 HRMARS

abilities, attitudes, and behavior of employees to do their work and thus attain organizational goals (Collins and Clark, 2003; Martinsons, 1995)

Previous literature has paid attention to the link between HRM practices and organizational performance such as productivity, flexibility, and financial performance (e.g., Ichniowski et al., 1997; Delery and Doty, 1996; Collins and Clark, 2003), but more understanding requires to be increased to incorporate innovation performance (Laursen and Foss, 2003). Therefore, the present study attempts to address the link between bundled HR practices and innovative performance from the knowledgebased view. For innovation to take place, organizations may leverage human capital to develop organizational expertise for creating new products and services. However, knowledge is much more complicated and is typically the results of conscious practices on representative tasks in the domain . These deliberate practices entail individuals wanting to perform the tasks and making efforts to improve performance. Organizations can identify and use a set of strategic HR practices to obtain the compliance and motivation of employees to involve in performing these susceptible practices to develop organizational expertise for business objectives such as innovation performance (Jacobs and Jones, 1995; Swanson, 1994). Accordingly, strategic HR practices can be conducive to innovative activities because strategic HR practices may allow firms to discover and utilize knowledge and expertise in the organization (Scarbrough, 2003).

Indeed, a growing body of literature has revealed the statistically significant relationship between HRM systems or in some researchers identified as HPWS; (ability, motivation, and opportunity)-enhancing human resource practices and firm performance (Gong, Chang, \& Cheung, 2010; Bello-Pintado, 2015). There is still uncertainty over the intermediary mechanisms that act as a link between the HPWS or HR systems and performance of the organizations (Boselie, Dietz, \& Boon, 2005). The extant literature on HPWS, there is no satisfactory evidence found that indicate the exact constituents of HRM practices and consequently explain the causality between HPWS Components and firm innovative performance. To unlock this so-called 'black box,' the current study has introduced knowledge process capability as a mediating variable in the research framework to bridge the causal gap between bundled HRM practices or HPWS and firm innovative performance. This study identified from most of the previous literature as it is primarily aimed to examine the performance effects of HPWS about the abilities, motivation, and opportunities (AMO) theory given by Appelbaum, Bailey, Berg, and Kalleberg (2000). Based on the Components of the AMO model, this study contributes to the current HRM literature by offering a distinct theoretical understanding and empirical evidence of how the HPWS components result in enhanced firm performance through their effects on the knowledge process capability and lastly innovative performance.

A majority of organizations assume enhanced performance to not only join on a successful disposition of tangible assets and natural sources but also on effective knowledge management (Lee $\&$ Sukoco, 2007). Consequently, knowledge management investments have been noted to increase throughout the years (Mills \& Smith, 2011). Presently, knowledge is the essential economic resource that is important to obtain sustainable competitive advantage and therefore, it is crucial for organizations to gain the right knowledge for the achievement of success (Anantatmula, 2007). 
Several reasons can be attached to the increasing value of knowledge management. First, to succeed in the dynamic global economy, organizations should decrease their cycle types consisting of production, operations limited to the least fixed assets and costs, product development time and they should enhance their customer service and product quality and maximize and enhance the productivity of employees and performance. In addition to the above, Gupta, Sharma and Hsu (2004) also added the importance of updating and restructuring of business processes and increasing agility and versatility.

All the above activities need continuous efforts focused towards the acquisition, creation, documentation, sharing, and application of knowledge among employees and teams in all levels of the organization. In other related studies in literature, Gharakhani and Mousakhani (2012) looked at the effect of KM capabilities (knowledge sharing, knowledge application, and knowledge acquisition) on Iranian organizations performance, They employed self-administered questionnaires for data collection from the 30 SMEs and found that knowledge management capabilities positively and significantly influenced organizational performance. Along with a similar line Gholami, Asli, NazariShirkouhi and Noruzy (2013) investigated the influence of KM practices, particularly knowledge sharing, knowledge creation, knowledge storage, knowledge acquisition, and knowledge implementation, on organizational performance in light of customer satisfaction, productivity, innovation, financial performance, staff performance and work relationships in the context of 282 SMEs in Iran. By their results, the KM practices directly affect the OP dimensions.

Although the extreme volume of research on innovative performance,(e.g. Anderson, De Dreu, \& Nijstad, 2004) and on human resource management (HRM), on the other hand (see e.g. Becker \& Huselid, 1998; Boxall \& Macky, 2009; Macduffie, 1995; for review), our knowledge base regarding the relationship between HRM and innovation has improved enough (De Leede \&Looise, 2005; Laursen \& Foss, 2014). Even though the first theoretical models developed in HRM and innovation presented ten years ago (De Leede \& Looise, 2005; Looise \& van Riemsdijk, 2004). The past few years, still, have observed the publication of an increasing number of empirical studies on this subject (e.g., Beugelsdijk, 2008; Chen \& Huang, 2008; Fu, Flood, Bosak, Morris, \& O’Regan, 2015; Perdomo-Ortiz, González-Benito, \& Galende, 2009). This development is not unexpected given that innovation is related to the resources of competitive advantage and performance (Becker \& Gerhart, 1996). The postulate is that an organization's capability to innovate remains in its employees' abilities and motivation and that HRM is associated in the whole innovation process because employees' output required for the development and implementation of innovations (Jiménez-Jiménez \& SanzValle, 2008)

\subsection{Innovative Performance}

Innovation in organizations is a comprehensive concept. It embraces a plenty of areas including various types of innovation, e.g. , product innovation (Dougherty, 1992; Eisenhardt and Tabrizi, 1995; Seidel and O'Mahony, 2014; Utterback and Abernathy, 1975; Zhou and Wu, 2010) technological innovation (Betz, 2011; Dosi, 1982; Lee and Kim, 2014; Teece, 1986) and management innovation (Birkinshaw et al, 2008; Helper and Sako, 2010; Peris-Ortiz and Hervás-Oliver, 2014); innovation processes, e.g., diffusion, adoption, and implementation (Adler and Kwon, 2013; Cooper and Zmud, 
INTERNATIONAL JOURNAL OF ACADEMIC RESEARCH IN BUSINESS AND SOCIAL SCIENCES Vol. 8, No. 11, Nov, 2018, E-ISSN: 2222-6990 @ 2018 HRMARS

1990; Kennedy and Fiss, 2009), innovation involvement, e.g., multiple actors approaches (Ibarra, 1993; Yeniyurt et al., 2014); and innovation as a performance outcome and (possible) indicator for organizational success (e.g. Armstrong et al., 2010; Chen and Huang, 2009). In this study, we use innovation as a performance outcome.

\subsection{HRM Practices}

Human resources are supposed to be one of the most important resources within an organization that helps in achieving competitive advantage (Wheelen \& Hunger, 2013). Nevertheless, it argued that managing human resources is more challenging than managing technology or capital (Tiwari \& Saxena, 2012). Human resources management (HRM) characterized as all decisions and practices that influence employees within organizations (Shahnawaz \& Juyal, 2006). HRM practices are described as "organizational activities directed at managing the pool of human resources and securing that the resources are employed towards the fulfillment of organizational goals" (Tiwari \& Saxena, 2012, p. 671). Organizations use HRM practices to mold the behaviors, attitudes, and insights of employees in a way to improve its performance and aspired outcomes (Chew, 2004; Juhdi, 2011). However, it must take into consideration that HRM practices are not fixed; they differ from one organization to another (Tiwari \& Saxena, 2012).

Many researchers defined different practices that associated with HRM; nevertheless, those practices can group into various categories such as recruitment, selection, training and development, motivation, and maintenance. This paper discusses human resources practices with concept of AMO model, given by Appelbaum, Bailey, Berg, and Kalleberg (2000), AMO model classified the HRM practices into bundles or systems that enhance employees Ability, motivation and opportunity to perform, or what known in some studies as high-performance work systems (HPWS).Highperformance work systems (HPWS) commonly used as a substitute label for strategic human resource management (SHRM) (Combs et al., 2006; Datta et al., 2005; Evans and Davis, 2005; Guthrie et al., 2009; Jiang et al., 2012; Way, 2002). There is no comprehensive agreement on the interpretation of HPWS (Boxall and Macky, 2009; Boxall and Purcell, 2003), it can be described as "a system of HRM practices designed to enhance employees' skills, involvement, and productivity in such a way that employees become a source of sustainable competitive advantage" (Lawler, 1992, 1996; Levine, 1995; Pfeffer, 1998; cited in Datta et al., 2005: 136). HPWS involves the use of staffing, training, and development, performance appraisal, and incentives (Fu, 2013; Fu et al., 2013; Gittell et al., 2010; Takeuchi et al., 2007)

\subsection{Knowledge Process Capability}

While researches provide many definitions of knowledge management, the most basic way knowledge management can define implies "any process or practice of creating, acquiring, capturing, sharing, and using knowledge, wherever it resides, to improve learning and performance in organizations" (Armstrong, 2006, p. 174). From the several definitions, knowledge management is recognized to be a process involved in several phases or activities (Kim \& Lee, 2010). Different researchers viewed the processes joined with knowledge management differently, for example, Bousa \& Venkitchalam (2013) described the knowledge management process as the creation, transfer, storage, and reuse of knowledge. Pinho et al. (2012) considered the KM process as the 
INTERNATIONAL JOURNAL OF ACADEMIC RESEARCH IN BUSINESS AND SOCIAL SCIENCES Vol. 8, No. 11, Nov, 2018, E-ISSN: 2222-6990 @ 2018 HRMARS

process of acquiring, creating, utilizing, and sharing of knowledge. Also, Allameh et al. (2011) stated that knowledge management is comprised of the methods of identification, capturing, sharing, disseminating, application, and storing of knowledge. This paper discusses the knowledge process capabilities, according to Huber's model which was developed in 1991 and adopted by JimenezJimenez \& Sanz-Valle (2013). This model includes four phases: knowledge acquisition, knowledge distribution, knowledge interpretation.

Knowledge acquisition from the external marketplace and the inside employees provides opportunities for firms to recombine current knowledge and create new knowledge (Yli-Renko et al., 2001). The newly acquired knowledge interacting with the existing knowledge can modify organizational knowledge stock (Nonaka and Takeuchi, 1995; Gold et al., 2001) and enhance the breadth and depth of knowledge available to the firm, thereby increasing the potential for new innovative outcomes (Galunic and Rodan, 1998; Li and Calantone, 1998; Yli-Renko et al., 2001). The knowledge-based view suggests that knowledge acquisition activities will enhance a firm's ability to achieve its role (Grant, 1996) efficiently. Firms with good capability to acquire external and internal knowledge would reduce uncertainty and perform a higher number of administrative and technological distinctiveness (Li and Calantone, 1998; Sarin and McDermott, 2003; Yli-Renko et al., 2001). Accordingly, this study argues that knowledge acquisition has a definite link with innovation performance

Knowledge acquisition involves the process of obtaining further knowledge and information. This new knowledge can get from internal sources or external sources to the organization. However, regardless of the source, the most significant determinant of this process is the motivation to obtain and create new knowledge by employees (Kim \& Lee, 2010; Jimenez-Jimenez \& Sanz-Valle, 2013). Organizations can acquire additional knowledge utilizing several techniques such as through important learning which refers to inherited knowledge from the founders of a firm. Experiential learning which is knowledge gained from experience, and vicarious learning which is knowledge acquired from other individuals and businesses (Jashapara, 2011) where Parker (2012) noted that creating relationships and alliances with different partners can positively influence an organization's ability to acquire knowledge.

Knowledge sharing indicates collective ideas or behavioral habits related to the expanse of learning among different individuals or units in an organization (Moorman and Miner, 1998). Prior research has discussed and demonstrated that knowledge sharing could lead to the increased innovativeness of the firm (e.g., (Szulanski, 1996; Tsai and Ghoshal, 1998; Dyer and Nobeoka, 2000; Tsai, 2001). In particular, scholars have argued previously that knowledge sharing implies the new combination of knowledge that has earlier existed separately, which possibly would result in process improvements or novel products (Schumpeter, 1912/1934; Kogut and Zander, 1992; Tsai and Ghoshal, 1998). Since knowledge exists within different individuals and different levels of the organization, organizational members need to share it to organize new routines and mental models (Galunic and Rodan, 1998; Nonaka and Takeuchi, 1995). Also, when individuals are enthusiastic to share and exchange knowledge, they can create collective learning and synergistic benefits from the processes of changing knowledge and resource ( Nonaka and Konno, 1998). Innovations come about 
when organizational members share their expertise and convert it into an explicit form of products or services (Von Krogh, 1998; Nonaka and Konno, 1998).

Hence, firms that can effectively share knowledge among members are likely to be more innovative. Knowledge application is a focal element in the knowledge management process (Grant, 1996). From the knowledge-based view, the value of individual and organizational knowledge remains primarily on its application because of stickiness and tacitness of knowledge (Grant, 1996; Spender, 1996). New product improvement and innovation require the application and combination of specialized knowledge inputs from many different areas (Yli-Renko et al., 2001). An extensive application of knowledge enables firms continuously to translate their organizational expertise into embodied products (Weisberg, 2006; Sarin and McDermott, 2003). By effectively implementing knowledge, individuals might make fewer mistakes or improve their efficiency and reduce redundancy ( Gold et al., 2001). Organizations force then ultimately be able to speed new product improvement and create more innovative production processing technologies and administrative systems (Sarin and McDermott, 2003). Accordingly, this study suggests that knowledge management capacity regarding an acquisition, sharing, and application provides a positive enrichment to the firm's innovation performance. Through effective knowledge management, the organization will be able to transform knowledge into innovative products, services, and therefore lead to better technical and administrative innovation outcomes.

\section{Problem Statement}

This paper identified the 'black box' issue between HRM and innovation through the AMO framework, the HRM-innovation relationship to be understood. Mediators, such as creativity and knowledge management, as explanatory mechanisms are mandatory to know why HRM impacts innovation. Seeck \& Diehl (2017) asserted that some insufficiently covered areas on HRM- Innovation calls for further research, for example, measurement of innovative performance and HRM should be more consistent, and the theoretical underpinnings of the relationship between HRM and innovative performance should establish. This paper tries to cover these areas with the insight of AMO, RBV, and knowledge-based view. Furthermore, there are only a few types of research conducted in this field of innovative performance and the factors that affect them from an employee's perspective in Jordanian banks in Jordan.

\section{Research Questions}

1. What is the relationship between (Ability, motivation and opportunity)-enhancing HRM practices and innovative performance?

2. Are (Ability, motivation and opportunity)-enhancing HRM practices related to knowledge process capability?

3. Is knowledge process capability associated with innovative performance?

4. Does knowledge process capability mediate the relationship between (Ability, motivation and opportunity)-enhancing HRM practices and innovative performance? 
INTERNATIONAL JOURNAL OF ACADEMIC RESEARCH IN BUSINESS AND SOCIAL SCIENCES

Vol. 8, No. 11, Nov, 2018, E-ISSN: 2222-6990 @ 2018 HRMARS

\section{Purpose of the Study}

The main purpose of this research is to examine the influence of (Ability, motivation and opportunity)-enhancing HRM practices and knowledge process capabilities on innovative performance within Jordanian banks .In addition, this research aims to:

1. To investigate the relationship between (Ability, motivation and opportunity)-enhancing HRM practices and innovative performance.

2. To determine the relationship between (Ability, motivation and opportunity)-enhancing HRM practices and knowledge process capability

3. To examine the relationship between knowledge process capability and innovative performance.

4. To identify the mediating effect of knowledge process capability on the relationship between (Ability, motivation and opportunity)-enhancing HRM practices and innovative performance.

\section{Theoretical Framework}

\subsection{Ability. Motivation and Opportunity (AMO) model}

Studies in recent years have turned their focus to the 'systems' view where HR practices saw as interrelated components of a system (MacDuffie, 1995; Gong, Chang, \& Cheung, 2010; Kundu \& Gahlawat, 2015). It has also perceived that there is a general trend among researchers to use a 'unidimensional index' of HR practices under the umbrella term 'HPWS' where each significant practice of the system is supposed to behave in an identical manner relative to the outcomes ( Dietz, \& Boon, 2005). Contrary to this postulation, a rising stream of research has suggested that the HR practices affect organizational performance in different ways (Gardner, Wright, \& Moynihan, 2011) and therefore, must conceptualize along the lines of the three domains based on AMO model. The AMO model represents the strategic relevance of HPWS explicitly by concentrating specifically on those HR practices that efficiently improve the discretionary behavior among employees (Appelbaum et al., 2000). First part 'ability' focuses on developing the capabilities of the employees for performance and includes practices like staffing, training, and coaching (Boselie, 2010; Jiang, Lepak, $\mathrm{Hu}, \&$ Baer, 2012). The second part 'motivation' is supposed to increase the employees' motivation for discretionary efforts and is comprised of the practices like performance appraisal, compensation, and rewards (Appelbaum et al., 2000; Jiang et al., 2012). The third part of opportunity' represents the open prospects for employees to contribute to the organizations' success and includes practices like information sharing, communication (Jiang et al., 2012). Furthermore, recent researches have suggested that the different subsets of HR systems may vary in their effects on performance; even they may influence the performance through distinct routes (Park, 2015).

\section{2. (Ability, motivation and opportunity)-enhancing HRM practices and innovative performance.}

Based on the theoretical background, practical support found for the HRM practices and organizational innovation link in different contexts. For example Cabello-Medina et al. (2011) determined that some HRM practices, e.g., development, selection, influence the creation of human capital which in turn promotes organization innovation. Their study also provides support for the impact of firms' innovation on organizational performance. Likewise, using a sample of 85 Spanish firms, using a longitudinal database from thirty-five UK manufacturing organizations, Shipton et al. 
INTERNATIONAL JOURNAL OF ACADEMIC RESEARCH IN BUSINESS AND SOCIAL SCIENCES Vol. 8, No. 11, Nov, 2018, E-ISSN: 2222-6990 @ 2018 HRMARS

(2005) observed that HRM systems promote organizational innovation in products and production technology. Jiménez-Jiménez and Sanz-Valle (2008) employed a sample from Spain and found that HRM enhances innovation which in turn provides positively to business performance.

Wei et al. (2011) found that strategic HRM has a positive influence on firms' product innovation and this relationship is greater for firms with a developmental culture. Besides these quantitative studies, De Saá-Pérez and Díaz-Díaz's (2010) study in an ultra-peripheral region of the European Union - the Canary Islands - provides support for the link between 'high commitment' human resource management and organizational innovation. Zanko et al. (2008) conducted an indepth case study on the failure of implementing new product development (concurrent engineering) by a Eurotech company. They demonstrated that this was due to the absence of HRM practices which resulted from the organizational power struggles within the firm. These HRM practices were found to be critically important for organizational innovation in new product development. Therefore, the link between HRM and organizational innovation established both theoretically and empirically, this study followed study of Huang\& Li (2009) by using administrative innovation and technical innovation to measure innovative performance, the following hypothesis represent the relationship between HRM practices and innovative performance.

Hypothesis 1a: Ability-enhancing HRM practices have positive and significant effect on innovative performance.

Hypothesis 1b: Motivation-enhancing HRM practices have positive and significant effect on innovative performance.

Hypothesis1c: Opportunity-enhancing HRM practices have positive and significant effect on innovative performance.

\subsection{HR Practices And Knowledge Management}

Early researches concentrate on the impacts of HR practices on organizational outcomes; few studies explore the influence of HR practices on knowledge management (e.g., Currie and Kerrin, 2003) and on innovation performance (e.g., Laursen and Foss, 2003). By taking an organizational learning perspective, Currie and Kerrin (2003) use case study approach to explore the influence of "strategic human resource practices," including performance management, recruitment and selection, and career development, on the process of knowledge sharing. They recommend that HRM practices can enhance knowledge sharing in the organization with a base of the organizational structure.

The measurement of HRM practices in prior studies was in different ways of coping with different purposes. This paper focuses on examining the impacts of HRM enhancing ability, motivation and opportunity practices on the innovative performance through the mediating effect of knowledge process capability. This study considers measures in prior studies using the concepts of HRM practices based on AMO model and bundled HRM practices (e.g. Youndt et al., 1996; Collins and Clark, 2003; Currie and Kerrin, 2003; Tannenbaum and Dupuree-Bruno, 1994; MacDuffie, 1995) as they are more relevant to the arguments of the relationships involving HR practices, knowledge management, and innovation. Accordingly, this study adopts three systems; Ability- enhancing HRM practices (staffing and training), motivation-enhancing HRM practices (performance appraisal and 
INTERNATIONAL JOURNAL OF ACADEMIC RESEARCH IN BUSINESS AND SOCIAL SCIENCES Vol. 8, No. 11, Nov, 2018, E-ISSN: 2222-6990 @ 2018 HRMARS

compensation and rewards), opportunity-enhancing HRM practices (communication and employee involvement).

Hypothesis 2a: Ability-enhancing HRM practices have positive and significant effect on knowledge process capability

Hypothesis 2b: Motivation-enhancing HRM practices have positive and significant effect on knowledge process capability

Hypothesis2c: Opportunity-enhancing HRM practices have positive and significant effect knowledge process capability

\subsection{Knowledge Management Capacity And Innovation Performance}

Organizational innovation, involving the advancement of new products or services as well as new administrative systems, is emerging as an essential source of sustainable competitive advantage ( Hurley and Hult, 1998). The innovation process involves the acquisition, distribution, and use of new and existing knowledge (Damanpour, 1991; Moorman and Miner, 1998). An organization's innovativeness closely tied to its ability to utilize its knowledge resources (Subramaniam and Youndt, 2005). Knowledge management is an approach of more actively leveraging the knowledge and expertise to create value and enhance organizational effectiveness (Gold et al., 2001; Ruggles, 1998; Scarbrough, 2003). Firms that exhibit a higher level of knowledge management capacity background a learning effect that can improve their capabilities in reducing repetition, responding rapidly to change, and developing creative ideas and innovation (Scarbrough, 2003). Effective knowledge management expedites knowledge dissemination and replacement required in the innovation process and further enhances innovation performance through the improvement of new insights and capabilities (Madhavan and Grover, 1998). Therefore, knowledge management capacity plays a pivotal role in supporting and fostering innovation. Since accomplishing knowledge in the innovation process is complicated, this study concentrates on those mechanisms that the organization uses to acquire, share, and apply new or improved knowledge.

Hypothesis 3: knowledge process capability has positive and significant effect on innovative performance.

\subsection{Mediating Effect of Knowledge Management Capacity}

The previous hypotheses link the relationships among (Ability, motivation, and opportunity)enhancing HRM practices, knowledge process capability, and innovative performance. Essentially, the discussion suggests that (Ability, motivation, and opportunity)-enhancing HRM practices affect firms' innovative performance through their knowledge process capability. That is, firms can use HR practices to improve the knowledge acquisition, sharing, and application, which, in turn, promote employees' capacity to innovate and enhance their innovation performance. Thus, this study argues that knowledge process capability plays a mediating role in the relationship between independent variables of (Ability, motivation, and opportunity)-enhancing HRM practices and the dependent variable of innovative performance. Following this line of reasoning, this study proposes the following hypothesis.

Hypothesis 4a: knowledge process capability mediate the relationship between Ability-enhancing HRM practices and innovative performance 
INTERNATIONAL JOURNAL OF ACADEMIC RESEARCH IN BUSINESS AND SOCIAL SCIENCES

Vol. 8, No. 11, Nov, 2018, E-ISSN: 2222-6990 C 2018 HRMARS

Hypothesis 4b: knowledge process capability mediate the relationship between Motivationenhancing HRM practices and innovative performance

Hypothesis 4c: knowledge process capability mediate the relationship between Opportunityenhancing HRM practices and innovative performance.

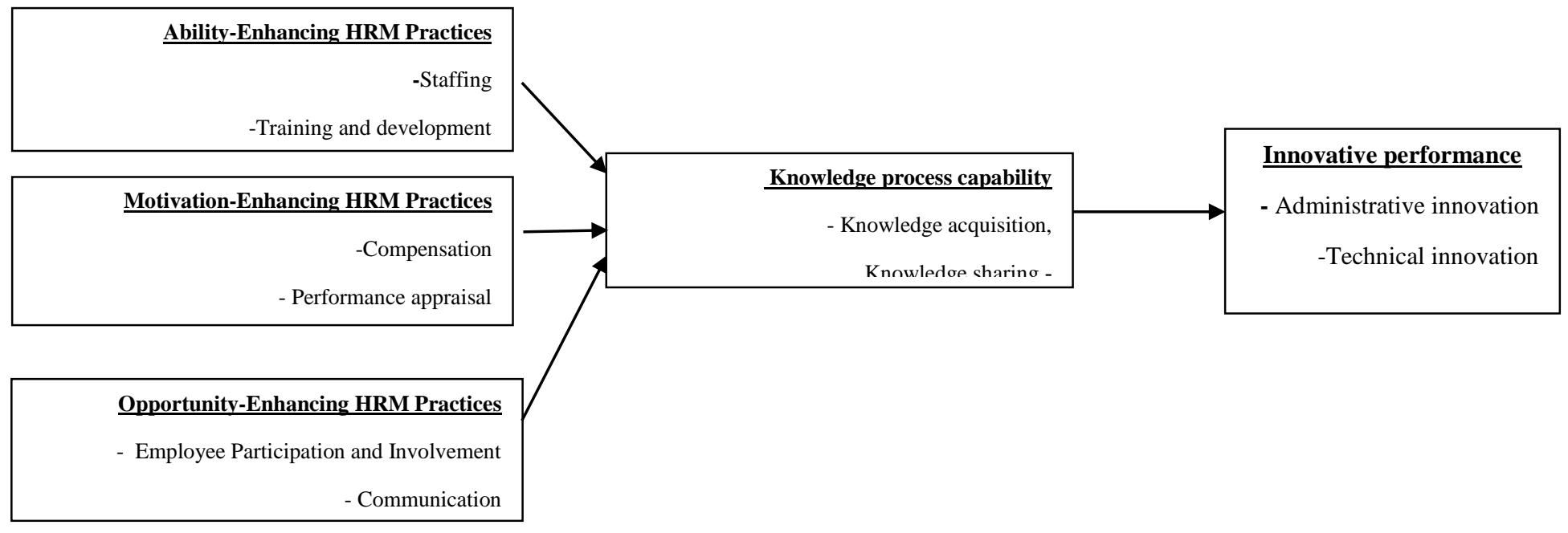

Figure 1: Theoretical framework of the study

\section{Research Methodology}

This paper aim is to examine the relationship between (Ability, motivation, and opportunity)enhancing HRM practices, and innovative performance with mediating role of knowledge process capability. Ability- enhancing HRM practices were measured using staffing; training, and development, motivation-enhancing HRM practices were measured using performance appraisals, and compensation, opportunity- enhancing HRM practices were measured using employee participation and involvement, communication study of Demo, Neiva and Rozzett, (2012). Innovative performance was measured used technical innovation and administrative innovation, study of Huang\& Li (2009). Finally, knowledge process capability; was measured by acquisition process, conversion process, application process, protection process study of Lee and Sukoco (2007).

\subsection{Data collection and sample}

Convince the questionnaire used to collect data. This questionnaire is composed of 60 questions that represent all the variables of this research. The questionnaire distributed to the headquarters of 25 banks in Jordan within Amman the central location of them. Due to the difficulty associated with reaching and accessing, In the present study a stratified random sampling method was used to determine the sample as the present study could determine significant differences in the bank sector. In general, the population of the study consists of four classifications of banks in Jordan, namely, international commercial banks, international Islamic banks, foreign commercial banks, and Islamic foreign banks. A random sample selected from 320, table 2 illustrates the type of banks and the population of each type and the sample size of each proportion. Moreover, to ensure a high 
INTERNATIONAL JOURNAL OF ACADEMIC RESEARCH IN BUSINESS AND SOCIAL SCIENCES Vol. 8, No. 11, Nov, 2018, E-ISSN: 2222-6990 @ 2018 HRMARS

response rate, a cover letter accompanied each questionnaire to respondents explaining the research objectives with the assurance of the confidentiality of the information they provided. This letter offered a brief introduction to the research and its objectives and requested permission to conduct the research. However, 214 questionnaires were submitted back with a response rate of $66 \%$. Respondents answered all items on ten point Likert-scales ranging from " 1 " "strongly disagree" to "10" "strongly disagree agree". Moreover, elements used to examine each of the constructs essentially taken from prior research. These elements provided a valued source for data gathering and measurement as their reliability and validity have been verified through previous research and peer review.

Table 2: Stratified random sampling of the study

\begin{tabular}{|l|l|l|}
\hline Sectors & No. of population & Proportion of 1.7\% \\
\hline National commercial banks & 14069 & 239 \\
\hline National Islamic banks & 3165 & 54 \\
\hline Foreign commercial banks & 1367 & 24 \\
\hline Forgiven Islamic banks & 170 & 3 \\
\hline Total & 18773 & 320 \\
\hline
\end{tabular}

\subsection{Pilot Study}

A pilot test described as a test that examines the design, method, and instrument before the actual research. It entails the initial test of data collection tools/processes to determine and rectify errors. The pilot test described by Zikmund, Babin, Carr, and Griffin (2010) as experimental testing of a small sample group, with the results being preparation for testing the study design. The test conducted before the actual survey, and it allows the researcher to delineate wrong questions. It also allows the researcher to gauge the time taken to complete the questionnaire. The pilot test measures the reliability and validity and determines the issues of errors in the survey. The internal reliability of the pilot test obtained through the use of Cronbach's alpha. The pilot test was also utilized to measure the research variables before the actual data collection in order to ensure that the study objectives achieved. Therefore, data collected from banks headquarter employees (managerial and no managerial), after which it was analyzed to obtain Cronbach's alpha values as presented in Table 3. Table 3 contains the reliability analysis results of the variables. 
INTERNATIONAL JOURNAL OF ACADEMIC RESEARCH IN BUSINESS AND SOCIAL SCIENCES Vol. 8, No. 11, Nov, 2018, E-ISSN: 2222-6990 @ 2018 HRMARS

Table 3: Reliability Result

\begin{tabular}{|l|l|l|l|}
\hline \multirow{2}{*}{ construct } & Variable & $\begin{array}{l}\text { No of items will be } \\
\text { measured }\end{array}$ & $\begin{array}{l}\text { Cronbach's } \\
\text { Alpha }\end{array}$ \\
\hline \multirow{2}{*}{ Innovative performance } & Technical innovation & 3 & 0.795 \\
\cline { 2 - 4 } & Administrative innovation & 3 & 0.821 \\
\hline $\begin{array}{l}\text { Ability-enhancing HRM } \\
\text { practices }\end{array}$ & staffing & 6 & 0.689 \\
\cline { 2 - 4 } $\begin{array}{l}\text { motivation-enhancing } \\
\text { HRM practices }\end{array}$ & Training and development & 6 & 0.775 \\
\hline \multirow{2}{*}{$\begin{array}{l}\text { opportunity-enhancing } \\
\text { HRM practices }\end{array}$} & Performance appraisal & 5 & 0.765 \\
\hline \multirow{3}{*}{$\begin{array}{l}\text { Knowledge infrastructure } \\
\text { capability }\end{array}$} & involvement & 5 & 0.691 \\
\cline { 2 - 4 } & Communication & 9 & 0.832 \\
\cline { 2 - 4 } & Acquisition process & 4 & 0.762 \\
\cline { 2 - 4 } & Application process & 6 & 0.865 \\
\cline { 2 - 4 } & Protection process & 3 & 0.771 \\
\hline
\end{tabular}

\section{Discussion and Conclusion}

This study examined the mediating role of Knowledge process capability on the relationship between (ability, motivation, and opportunity)-enhancing HRM practices and innovative performance. In the context of Jordanian banks. The study findings contribute to literature regarding the relationship among the study variables. Additionally, researchers have recommended the examination of such relationship Seeck \& Diehl, (2017). A literature review on HRM and innovationtaking stock and future directions. The International Journal of Human Resource Management, 28(6), 913-944. The findings showed that( ability, motivation, and opportunity)-enhancing HRM practices banks in Jordan affect their innovative performance as well as knowledge capability process for example knowledge sharing and knowledge protection influenced by HRM practices ( training, communication), the result of the study shows that knowledge process capability mediates the relationship between HRM practices and innovative performance.

\section{References}

Seeck, H., \& Diehl, M. R. (2017). A literature review on HRM and innovation-taking stock and future directions. The International Journal of Human Resource Management, 28(6), 913-944.

Huang, J. W., \& Li, Y. H. (2009). The mediating effect of knowledge management on social interaction and innovation performance. International journal of Manpower, 30(3), 285-301.

Zikmund, Babin, B., Carr, J., \& Griffin, M. (2010). Business Research Methods, South-Western, Cengage Learning. Mason, $\mathrm{OH}$. 
INTERNATIONAL JOURNAL OF ACADEMIC RESEARCH IN BUSINESS AND SOCIAL SCIENCES Vol. 8, No. 11, Nov, 2018, E-ISSN: 2222-6990 @ 2018 HRMARS

Demo, G., Neiva, E. R., Nunes, I., \& Rozzett, K. (2012). Human resources management policies and practices scale (HRMPPS): Exploratory and confirmatory factor analysis. BAR-Brazilian Administration Review, 9(4), 395-420.

Lee, L. T. S., \& Sukoco, B. M. (2007). The effects of entrepreneurial orientation and knowledge management capability on organizational effectiveness in Taiwan: the moderating role of social capital. International Journal of Management, 24(3), 549.

Huang, J. W., \& Li, Y. H. (2009). The mediating effect of knowledge management on social interaction and innovation performance. International journal of Manpower, 30(3), 285-301.

Madhavan, R., \& Grover, R. (1998). From embedded knowledge to embodied knowledge: new product development as knowledge management. The Journal of marketing, 1-12.

Scarbrough, H. (2003). Knowledge management, HRM and the innovation process. International journal of manpower, 24(5), 501-516.

Gold, A. H., Malhotra, A., \& Segars, A. H. (2001). Knowledge management: An organizational capabilities perspective. Journal of management information systems, 18(1), 185-214.

Ruggles, R. (1998). The state of the notion: knowledge management in practice. California management review, 40(3), 80-89.

Subramaniam, M., \& Youndt, M. A. (2005). The influence of intellectual capital on the types of innovative capabilities. Academy of Management journal, 48(3), 450-463.

Hurley, R. F., \& Hult, G. T. M. (1998). Innovation, market orientation, and organizational learning: an integration and empirical examination. The Journal of marketing, 42-54.

Noor Azinuddin, A. (2015). The relationship between innovation and information technology on organizational performance. Universiti Utara Malaysia

Minbaeva, D. (2008). HRM practices affecting extrinsic and intrinsicnmotivation of knowledge receivers and their effect on intra- MNC knowledge transfer. International business review, 17(6), 703-713

Ghoneim, A., \& El-Tabie, N. (2014, October). Effect of Internal Marketing Adoption on the Performance of the Commercial Banks in Egypt. In Proceedings of 9th International Business and Social Science Research Conference.

Matzler, K., \& Renzl, B. (2007). Assessing asymmetric effects in the formation of employee satisfaction. Tourism Management, 28(4), 1093-1103. 
INTERNATIONAL JOURNAL OF ACADEMIC RESEARCH IN BUSINESS AND SOCIAL SCIENCES Vol. 8, No. 11, Nov, 2018, E-ISSN: 2222-6990 C 2018 HRMARS

Ortega-Parra, A., \& Ángel Sastre-Castillo, M. (2013). Impact of perceived corporate culture on organizational commitment. Management Decision, 51(5), 1071-1083.

Juhdi, N., Pa'wan, F., Hansaram, R. M., Kaur, S., \& Othman, N. A. (2011). HR practices, organizational commitment and turnover intention: A study on employees in Klang Valley, Malaysia.

Bimpitsos, C., \& Petridou, E. (2012). A transdisciplinary approach to training: preliminary research findings based on a case analysis. European Journal of Training and Development, 36(9), 911-929.

Vanhala, S., \& Stavrou, E. (2013). Human resource management practices and the HRM-performance link in public and private sector organizations in three Western societal clusters. Baltic Journal of Management, 8(4), 416-437.

Savaneviciene, A., \& Stankeviciute, Z. (2011). Human resource management practices linkage with organizational commitment and job satisfaction. Economics \& Management, 16.

Subramaniam, M., \& Youndt, M. A. (2005). The influence of intellectual capital on the types of innovative capabilities. Academy of Management journal, 48(3), 450-463.

Barney, J., Wright, M., \& Ketchen Jr, D. J. (2001). The resource-based view of the firm: Ten years after 1991. Journal of management, 27(6), 625-641. 